Article

\title{
On the comparable activity in plasmonic photocatalytic and thermocatalytic oxidative homocoupling of alkynes over prereduced copper ferrite
}

\author{
Ying Zhu †, Nan Deng †, Meiqing Feng, Peng Liu* \\ Key Laboratory of Material Chemistry for Energy Conversion and Storage (Ministry of Education), Hubei Key Laboratory of Material Chemistry and \\ Service Failure, School of Chemistry and Chemical Engineering, Huazhong University of Science and Technology, Wuhan 430074, Hubei, China
}

\section{A R T I C L E I N F O}

\section{Article history:}

Received 10 June 2019

Accepted 6 July 2019

Published 5 October 2019

\section{Keywords:}

Alkyne

Homocoupling

Copper ferrite

Copper nanoparticles

Surface plasmon resonance

\begin{abstract}
A B S T R A C T
Despite of extensive attention on the copper-based heterogeneous oxidative homocoupling of alkynes (OHA) to 1,3-diynes, the photocatalytic OHA is scarcely investigated. By screening copper-containing spinel catalysts, we discovered that a prereduced copper ferrite $\left(\mathrm{CuFe}_{2} \mathrm{O}_{4}\right)$ not only can catalyze the thermocatalytic OHA but also is efficient for the photocatalytic OHA under visible light irradiation. It is found that the sol-gel combustion (SG) method and the partial reduction at $250{ }^{\circ} \mathrm{C}$ can result in the optimal $\mathrm{CuFe}_{2} \mathrm{O}_{4}-\mathrm{SG}-250$ catalyst showing high activity and stability. Surface oxidized $\mathrm{Cu}_{2} \mathrm{O}$ is evidenced to be the active species for the thermocatalytic OHA, whereas metallic copper nanopaticles (CuNPs) are identified as the active sites for the photocatalytic OHA. The efficiency of photocatalytic $\mathrm{OHA}$ at ambient temperature is comparable to that of thermocatalytic $\mathrm{OHA}$ at $120{ }^{\circ} \mathrm{C}$, and the $\mathrm{CuFe}_{2} \mathrm{O}_{4}$-SG-250 catalyst can be magnetically separated and reused at least five times. The localized surface plasmon resonance effect of CuNPs contributes to visible light-induced photocatalytic OHA.
\end{abstract}

(C) 2019, Dalian Institute of Chemical Physics, Chinese Academy of Sciences. Published by Elsevier B.V. All rights reserved.

\section{Introduction}

Considerable attention has been paid to the development of efficient methods for the synthesis of conjugated 1,3-diynes, because these compounds are important building blocks for the synthesis of natural products, pharmaceuticals, optoelectronic materials and polymers [1-3]. Copper-catalyzed oxidative homocoupling of alkynes (OHA), also known as Glaser-Hay coupling, is considered a classic route to the symmetrical conjugated 1,3-diynes [4-6]. From a practical viewpoint, heterogeneous copper catalysts are more advantageous over the homogeneous counterparts due to their easy recovery and recycling as well as enhanced stability [6-8]. Although various support materials have been used to immobilize copper species for the OHA reactions, most of the heterogeneous systems are effective only in the presence of nitrogen-containing ligands or base additives [7,9-19], which usually bring corrosion and pollution problem. Therefore, it is an attractive and challenging goal to develop efficient heterogeneous copper catalysts that can perform the green synthesis of conjugated 1,3-diynes under ligand- and base-free conditions.

To address the above challenge, inorganic oxide-supported copper catalysts have been explored [20-26]. Mixed oxides containing undefined $\mathrm{Cu}^{+} / \mathrm{Cu}^{2+}$ composition, such as $\mathrm{Cu}(\mathrm{OH})_{x} / \mathrm{MnO}_{2}$ [22], $\mathrm{CuO}_{x} / \mathrm{TiO}_{2}$ [23,24], $\mathrm{CuO}_{x} / \mathrm{MnO}_{x}$ [25] and $\mathrm{CuO}_{x} / \mathrm{Fe}_{3} \mathrm{O}_{4}$ [26] were used as recyclable catalysts for the addi-

\footnotetext{
* Corresponding author. Tel/Fax: +86-27-87543632; E-mail: pengliu@hust.edu.cn

+ These authors contributed equally to this work.

This work was supported by the National Natural Science Foundation of China (21673088).

DOI: S1872-2067(19)63418-2 | http://www.sciencedirect.com/science/journal/18722067 | Chin. J. Catal., Vol. 40, No. 10, October 2019
} 
tive-free $\mathrm{OHA}$ in toluene at $90-180{ }^{\circ} \mathrm{C}$. Despite these important progress, the nature of active copper species remains unclear. For practical application, if the heterogeneous additive-free OHA reaction can be readily carried out at room temperature (RT), it would remarkably reduce energy consumption and be more economically competitive and environmentally benign. However, examples of such green OHA process are scarce.

The utilization of solar energy to drive catalytic chemical transformations is one of the most promising strategies to substantially reduce the energy consumption in the future [27]. Especially, visible light-induced transition metal-catalyzed organic reactions are recognized as powerful alternatives to metal-catalyzed "thermal" reactions, since visible light-mediated reactions are normally performed at RT in the absence of ligands or bases [28]. Visible light-induced copper-catalyzed homogeneous reactions in the absence of exogenous photosensitizers mainly involve $\mathrm{C}-\mathrm{C}$ and $\mathrm{C}-\mathrm{N}$ coupling, and $\mathrm{C} \equiv \mathrm{C}$ oxidation reactions [29]. Hwang's group firstly reported a visible light-induced $\mathrm{OHA}$ reaction at $\mathrm{RT}$ with $\mathrm{CuCl}$ as the catalyst in $\mathrm{CH}_{3} \mathrm{CN}$ under blue LED irradiation [30]. For heterogeneous photocatalytic organic reactions over copper catalysts, there are only few reports focused on the localized surface plasmon resonance (LSPR) effect of copper nanoparticles (CuNPs) for alkene epoxidation, C-N/C-O/C-S and N-N couplings [31-36]. To our knowledge, visible light-driven heterogeneous copper-catalyzed OHA reaction has not yet been reported.

Since $\mathrm{Cu}^{+}$species plays important role in homogeneous photocatalytic and heterogeneous thermocatalytic OHA reactions, there would be opportunity to use $\mathrm{Cu}^{+}$-containing mixed oxides to develop effective heterogeneous photocatalyst for additive-free $\mathrm{OHA}$ reactions. Intrigued by our previous findings on the synergistic effect of $\mathrm{Cu}^{+}$-containing spinel supports on the oxidative dehydrogenation of alcohol [37-41], we employed these $\mathrm{Cu}^{+}$-containing chromite, aluminate and ferrite spinels in exploring the heterogeneous thermocatalytic and photocatalytic OHA reactions under additive-free conditions. The results evidently indicate that catalyst pretreatment by $\mathrm{H}_{2}$ is crucial for both the thermocatalytic and photocatalytic reactions, and copper ferrite $\left(\mathrm{CuFe}_{2} \mathrm{O}_{4}\right)$ outperforms the other spinels. Surprisingly, the photocatalytic OHA under visible light irradiation at RT shows comparable catalytic efficiency to the thermocatalytic $\mathrm{OHA}$ at $120{ }^{\circ} \mathrm{C}$. Furthermore, the preparation method of $\mathrm{CuFe}_{2} \mathrm{O}_{4}$ and the pretreatment temperature strongly influence the catalytic performance. Controlled experiments demonstrate that surface oxidized $\mathrm{Cu}_{2} \mathrm{O}$ is the active species for the thermocatalytic OHA and metallic CuNPs are the active species for the photocatalysis. The LSPR effect of CuNPs contributes to the visible light-induced photocatalytic OHA.

\section{Experimental}

\subsection{Materials}

Metal nitrates $\left(\mathrm{Cu}\left(\mathrm{NO}_{3}\right)_{2} \cdot 3 \mathrm{H}_{2} \mathrm{O}, \quad \mathrm{Mg}\left(\mathrm{NO}_{3}\right)_{2} \cdot 6 \mathrm{H}_{2} \mathrm{O}\right.$, $\left.\mathrm{Al}\left(\mathrm{NO}_{3}\right)_{3} \cdot 9 \mathrm{H}_{2} \mathrm{O}, \mathrm{Cr}\left(\mathrm{NO}_{3}\right)_{3} \cdot 9 \mathrm{H}_{2} \mathrm{O}, \mathrm{Fe}\left(\mathrm{NO}_{3}\right)_{3} \cdot 9 \mathrm{H}_{2} \mathrm{O}\right)$, citric acid, ethylene glycol, and various analytically pure solvents were purchased from Sinopharm Chemical Reagent Co., Ltd. Copper
(I) oxide $\left(\mathrm{Cu}_{2} \mathrm{O}, 99 \%\right)$, cupric oxide $(\mathrm{CuO}, 99 \%)$, phenylacetylene (97\%), 4-methoxyl-phenylacetylene (98\%), 4-methylphenylacetylene (98\%), 4-Cl-phenylacetylene (98\%), 1,4-diphenylbutadiyne (98\%) and $n$-dodecane (99\%) were purchased from Adamas Reagent Co., Ltd. 1-heptyne (99\%), propargyl acetate $(97 \%)$ and copper powder $\left(\mathrm{Cu}^{0}, 99.9 \%\right)$ were purchased from Alfa Aesar. 3-methyl-phenylacetylene (98\%) was purchased from TCI. Triiron tetraoxide $\left(\mathrm{Fe}_{3} \mathrm{O}_{4}, 97 \%\right)$ and titanium dioxide $\left(\mathrm{TiO}_{2}, 99.5 \%\right)$ were purchased from Aldrich. All chemicals were used as received.

\subsection{Catalyst preparation}

Spinels $\quad \mathrm{MgCuCr}_{2} \mathrm{O}_{4}, \quad \mathrm{CuCr}_{2} \mathrm{O}_{4}, \quad \mathrm{MgCuAl}_{2} \mathrm{O}_{4}, \quad \mathrm{CuAl}_{2} \mathrm{O}_{4}$, $\mathrm{MgCuFe}_{2} \mathrm{O}_{4}, \mathrm{CuFe}_{2} \mathrm{O}_{4}$ ) prepared by co-precipitation method (designated as spinel-CP hereafter), in which the ternary $\mathrm{MgCuM}_{2} \mathrm{O}_{4} \quad(\mathrm{M}=\mathrm{Cr}, \mathrm{Al}, \mathrm{Fe})$ is the abbreviation of $\mathrm{Mg}_{0.75} \mathrm{Cu}_{0.25} \mathrm{M}_{2} \mathrm{O}_{4}$, were reported in our previous paper [41] and used directly in this work. To prepare $\mathrm{CuFe}_{2} \mathrm{O}_{4}$ by a different method, a sol-gel combustion (SG) method was employed as follows: the nitrates containing $\mathrm{Cu}^{2+}$ and $\mathrm{Fe}^{3+}$ in the stoichiometric quantity for synthesis of $10 \mathrm{~g}$ of the product were dissolved in deionized water $(50 \mathrm{~mL})$, then citric acid $(6 \mathrm{~g})$ and ethylene glycol ( $3 \mathrm{~mL}$ ) were added; the resulting solution was evaporated in a sand bath, in the end, the gel mixture got inflamed to produce an amorphous precursor; the precursor was calcined in air at $700{ }^{\circ} \mathrm{C}$ for $5 \mathrm{~h}$ to yield the $\mathrm{CuFe}_{2} \mathrm{O}_{4}$-SG sample. The $\mathrm{CuFe}_{2} \mathrm{O}_{4}$-SG was pretreated by $\mathrm{H}_{2}$ at $150,200,250$ and 300 ${ }^{\circ} \mathrm{C}$ to give $\mathrm{CuFe}_{2} \mathrm{O}_{4}-\mathrm{SG}-150, \mathrm{CuFe}_{2} \mathrm{O}_{4}$-SG-200, $\mathrm{CuFe}_{2} \mathrm{O}_{4}$-SG-250 and $\mathrm{CuFe}_{2} \mathrm{O}_{4}-\mathrm{SG}-300$ catalysts, respectively. Similarly, the spinel-CP samples were pretreated by $\mathrm{H}_{2}$ to afford spinel-CP-T catalysts, where $\mathrm{T}$ is the reduction temperature. The reference $\mathrm{Cu} / \mathrm{Fe}_{3} \mathrm{O}_{4}$ and $\mathrm{Cu} / \mathrm{TiO}_{2}$ catalysts with 5 wt\% copper loading were prepared by incipient wetness impregnation using $\mathrm{Cu}\left(\mathrm{NO}_{3}\right)_{2} \cdot 3 \mathrm{H}_{2} \mathrm{O}$ aqueous solution. After impregnation, the paste precursors were dried at $60{ }^{\circ} \mathrm{C}$ for $12 \mathrm{~h}$, then the catalysts were obtained by treating with $10 \mathrm{vol}^{\circ} \mathrm{H}_{2}$ at $350{ }^{\circ} \mathrm{C}$ for $2 \mathrm{~h}$.

\subsection{Catalyst characterization}

X-ray diffraction (XRD) was performed on an Empyrean apparatus using $\mathrm{Cu} K_{\alpha}$ radiation $(40 \mathrm{kV}$ and $30 \mathrm{~mA}$ ). Nitrogen physisorption was done on a Tristar 3000 automated gas adsorption system. High resolution transmission electron microscopy (HRTEM) images were acquired on a FEI Tecnai G2 F30 electron microscope. The magnetization and coercivity of the $\mathrm{CuFe}_{2} \mathrm{O}_{4}$ samples were measured by using a Model 3472-70 GMW vibrating sample magnetometer (VSM) with a maximum magnetic field of 15 kOe. The amount of surface acid-dissolvable copper species was determined by a Perkin Elmer AA-300 atomic absorption spectrometer (AAS) after treating the mixed oxides in nitric acid. Ultraviolet-visible (UV-vis) spectra were recorded by a Varian Cary 5000 spectrophotometer in a diffusion reflectance mode with $\mathrm{BaSO}_{4}$ as a reference. Temperature-programmed reduction (TPR) experiments were performed on Micrometrics AutoChem 2920II instrument. Typically, $20 \mathrm{mg}$ of the sample was loaded in a 
U-shape quartz tube and pretreated in $\mathrm{Ar}$ at $350^{\circ} \mathrm{C}$ for $1 \mathrm{~h}$. After cooling to room temperature in flowing $\mathrm{Ar}$, the sample was reduced in $10 \mathrm{vol} \% \mathrm{H}_{2}$ in $\mathrm{Ar}$ at a flow rate of $10 \mathrm{~mL} / \mathrm{min}$, while it was heated from room temperature up to $800{ }^{\circ} \mathrm{C}$ at a ramp rate of $10^{\circ} \mathrm{C} / \mathrm{min}$. The outlet gas was detected by the thermal conductivity detector. X-ray photoelectron spectroscopic (XPS) measurements were conducted on an AXIS-ULTRA DLD-600W spectrometer with $\mathrm{Al} \mathrm{K \alpha}$ irradiation and the binding energies were calibrated by using the $\mathrm{C} 1 s$ peak of contaminant carbon at $284.5 \mathrm{eV}$ as an internal standard.

\subsection{Catalytic tests}

For thermocatalytic OHA reactions, a typical procedure is as follows. A mixture of alkyne $(0.2 \mathrm{mmol}), n$-dodecane $(0.1 \mathrm{mmol}$, as internal standard), spinel or reduced spinel catalysts (20 $\mathrm{mg}$ ), and dimethylsulfoxide (DMSO, $2 \mathrm{~mL}$ ) was added into a 15 $\mathrm{mL}$ Pyrex glass tube ( $\phi 15 \mathrm{~mm}$ ) equipped with a condenser and an oxygen balloon. The reaction mixture was heated to $120{ }^{\circ} \mathrm{C}$ under vigorous stirring (700 rpm) for the required time. After the reaction was stopped by addition of ethyl acetate $(5 \mathrm{~mL})$, a portion of the mixture $(1 \mathrm{~mL})$ was filtered through a Titan filter (pore size $0.22 \mu \mathrm{m}$ ) to remove the catalyst particulates. The products were qualitatively analyzed by an Agilent 7890A/5975C GC-MS. Quantitative analysis was done on a Fuli 9070 GC-FID using an internal standard technique. In all cases, 1,3-diyne was the only product with $100 \%$ selectivity and the carbon balances were $100 \% \pm 3 \%$.

Photocatalytic OHA reactions were conducted in a light-reaction chamber connected to an air conditioner, which keeps room temperature at $20^{\circ} \mathrm{C}$. Typically, a mixture of alkyne (0.2 mmol), $n$-dodecane $(0.1 \mathrm{mmol}$, as internal standard), reduced spinel catalysts $(20 \mathrm{mg})$, and ethanol (2 mL) was added into a $15 \mathrm{~mL}$ Pyrex glass tube $(\varphi 15 \mathrm{~mm})$ equipped with an oxygen balloon and a temperature meter. Then the tube was stirred magnetically (700 rpm) at RT and irradiated with visible light of a light-emitting diode (PLS-LED 100, Beijing Perfectlight Technology Co. LTD). Four LED light sources with different wavelength in the range of 400-500/480-580/ $580-680 / 400-780 \mathrm{~nm}$ were used and denoted as blue/green/red/white LED hereafter, respectively. The light intensity was set to $0.2 \mathrm{~W} / \mathrm{cm}^{2}$ unless otherwise specified. Due to the heating effect of LED irradiation, the reaction in the dark was maintained the same temperature $\left(30{ }^{\circ} \mathrm{C}\right)$ as the photocatalytic reaction to make sure that the comparison is meaningful. All the reactions in the dark were conducted using a water bath and the tube was wrapped with aluminum foil. After the reaction, similar treatment and analysis procedures as the above thermocatalytic reaction were performed. In all cases, 1,3-diyne was the only product with $100 \%$ selectivity and the carbon balances were $100 \% \pm 3 \%$.

\section{Results and discussion}

\subsection{Screening catalysts for thermocatalytic and photocatalytic OHA}

We initially studied the thermocatalytic oxidative homocoupling of phenylacetylene over the untreated spinel-CP samples under the similar reaction conditions (at $110^{\circ} \mathrm{C}$ for $3 \mathrm{~h}$ in toluene) as the $\mathrm{CuO}_{x} / \mathrm{TiO}_{2}$-catalyzed OHA reactions [24]. However, various spinels showed negligible activity (1,3-diyne yield < $1 \%)$. The very low activity of the spinel-CP samples may be due to their low surface area (4-14 $\mathrm{m}^{2} / \mathrm{g}$ ) and thus low surface available copper species. To increase the surface copper species, all spinel-CP samples were pretreated by $10 \% \mathrm{H}_{2}$ in $\mathrm{N}_{2}$ at $300{ }^{\circ} \mathrm{C}$ for $2 \mathrm{~h}$. Because $\mathrm{CuFe}_{2} \mathrm{O}_{4}-\mathrm{CP}$ is the most reducible and could be reduced to $\mathrm{Cu}^{0}$ and $\mathrm{Fe}_{3} \mathrm{O}_{4}$ below $300{ }^{\circ} \mathrm{C}$ [41], we employed the $\mathrm{CuFe}_{2} \mathrm{O}_{4}-\mathrm{CP}-300$ to screen the reaction solvent and temperature (Table 1). To our delight, the OHA reaction per-

Table 1

Thermocatalytic and photocatalytic oxidative homocoupling of phenylacetylene over various catalysts.

\begin{tabular}{|c|c|c|c|c|c|c|c|}
\hline \multirow{2}{*}{ Entry } & \multirow{2}{*}{ Catalyst } & \multicolumn{3}{|c|}{ Thermocatalytic OHA } & \multicolumn{3}{|c|}{ Photocatalytic OHA } \\
\hline & & Solvent & Temp. $\left({ }^{\circ} \mathrm{C}\right)$ & Yield c (\%) & Solvent & Temp. $\left({ }^{\circ} \mathrm{C}\right)$ & Yield c $(\%)$ \\
\hline 1 & $\mathrm{CuFe}_{2} \mathrm{O}_{4}-\mathrm{CP}-300$ & EtOH & 80 & $<1$ & DMSO & 30 & 66 \\
\hline 2 & $\mathrm{CuFe}_{2} \mathrm{O}_{4}-\mathrm{CP}-300$ & $\mathrm{CH}_{3} \mathrm{CN}$ & 80 & 2 & DMF & 30 & 43 \\
\hline 3 & $\mathrm{CuFe}_{2} \mathrm{O}_{4}-\mathrm{CP}-300$ & Dioxane & 100 & $<1$ & Toluene & 30 & 3 \\
\hline 4 & $\mathrm{CuFe}_{2} \mathrm{O}_{4}-\mathrm{CP}-300$ & Toluene & 110 & $<1$ & Dioxane & 30 & 6 \\
\hline 5 & $\mathrm{CuFe}_{2} \mathrm{O}_{4}-\mathrm{CP}-300$ & DMF & 120 & 10 & THF & 30 & 7 \\
\hline 6 & $\mathrm{CuFe}_{2} \mathrm{O}_{4}-\mathrm{CP}-300$ & DMSO & 90 & 13 & $\mathrm{CH}_{3} \mathrm{CN}$ & 30 & 76 \\
\hline 7 & $\mathrm{CuFe}_{2} \mathrm{O}_{4}-\mathrm{CP}-300$ & DMSO & 100 & 20 & i-PrOH & 30 & 70 \\
\hline 8 & $\mathrm{CuFe}_{2} \mathrm{O}_{4}-\mathrm{CP}-300$ & DMSO & 110 & 50 & $\mathrm{MeOH}$ & 30 & 89 \\
\hline 9 & $\mathrm{CuFe}_{2} \mathrm{O}_{4}-\mathrm{CP}-300$ & DMSO & 120 & 88 & EtOH & 30 & 92 \\
\hline 10 & $\mathrm{MgCuFe}_{2} \mathrm{O}_{4}-\mathrm{CP}-300$ & DMSO & 120 & 5 & EtOH & 30 & 17 \\
\hline 11 & $\mathrm{CuCr}_{2} \mathrm{O}_{4}-\mathrm{CP}-300$ & DMSO & 120 & 75 & EtOH & 30 & 53 \\
\hline 12 & $\mathrm{MgCuCr}_{2} \mathrm{O}_{4}-\mathrm{CP}-300$ & DMSO & 120 & 49 & EtOH & 30 & 1 \\
\hline 13 & $\mathrm{CuAl}_{2} \mathrm{O}_{4}-\mathrm{CP}-300$ & DMSO & 120 & 50 & EtOH & 30 & 34 \\
\hline 14 & $\mathrm{MgCuAl}_{2} \mathrm{O}_{4}-\mathrm{CP}-300$ & DMSO & 120 & 3 & EtOH & 30 & 24 \\
\hline
\end{tabular}

Reaction conditions: phenylacetylene $(0.2 \mathrm{mmol}), n$-dodecane $(0.1 \mathrm{mmol})$ and catalyst $(20 \mathrm{mg})$ in the solvent $(2 \mathrm{~mL})$ under an $\mathrm{O}_{2}$ atmosphere for $3 \mathrm{~h}$. a Thermocatalytic OHA reaction was carried out by heating at certain temperature. ${ }^{b}$ Photocatalytic OHA reaction was performed under white LED irradiation $\left(0.2 \mathrm{~W} / \mathrm{cm}^{2}\right)$ at ambient temperature $\left(30^{\circ} \mathrm{C}\right) .{ }^{\mathrm{c}}$ Yields were determined by $\mathrm{GC}$. 
formed in DMSO at $120^{\circ} \mathrm{C}$ for $3 \mathrm{~h}$ can achieve the highest 1,3-diyne yield (88\%), which is comparable to the best results obtained by the previously reported preferred $\mathrm{CuO}_{x} / \mathrm{TiO}_{2}$ (yield up to $94 \%$ ) [24]. Under the identical reaction conditions, the other spinel-CP-300 catalysts showed inferior activity to the $\mathrm{CuFe}_{2} \mathrm{O}_{4}-\mathrm{CP}-300$, primarily due to the lower surface copper species in the former. It is needed to point out that the unreduced spinel-CP samples showed no activity even under the optimal conditions.

With the aim to develop green heterogeneous photocatalytic OHA reaction at RT, we employed white LED as light source because of its lower cost and energy consumption than a halogen lamp. Firstly, we investigated the effect of various solvents on the $\mathrm{CuFe}_{2} \mathrm{O}_{4}$-CP-300-catalyzed oxidative homocoupling of phenylacetylene under visible light irradiation (Table 1). Polar solvents are better than nonpolar solvents in this heterogeneous photocatalytic OHA reaction. Some polar solvents, such as DMSO, $\mathrm{CH}_{3} \mathrm{CN}, 2-\mathrm{PrOH}$ and $\mathrm{MeOH}$, resulted in moderate to high yield (66\%-89\%) of 1,3-diyne. Interestingly, when the nontoxic EtOH was used as a solvent, the highest yield (92\%) was achieved. With ethanol as the optimal solvent, the other spinel-CP-300 catalysts also showed much lower activity than the $\mathrm{CuFe}_{2} \mathrm{O}_{4}-\mathrm{CP}-300$. In contrast, the unreduced spinel-CP samples are inactive in the photocatalytic $\mathrm{OHA}$ and the $\mathrm{CuFe}_{2} \mathrm{O}_{4}-\mathrm{CP}-300$ shows no activity in the dark even at $80{ }^{\circ} \mathrm{C}$ (Table 1 , entry 1 ). Undoubtedly, we found a novel $\mathrm{CuFe}_{2} \mathrm{O}_{4}-\mathrm{CP}-300$ photocatalyst, which is efficient for the heterogeneous photocatalytic OHA under visible light irradiation.

On the basis of above results, it is evident that the reducibility and the amount of surface copper species of the $\mathrm{CuFe}_{2} \mathrm{O}_{4}$ spinel is crucial for both the thermocatalytic and the photocatalytic OHA reactions. Since the reducibility and surface composition of mixed oxides can be tuned by different preparation methods and reduction temperatures [40-43], there would be great opportunity to further enhance the catalytic efficiency by improving the reducibility and surface copper species of copper ferrite.

\subsection{Optimization of the prereduced $\mathrm{CuFe}_{2} \mathrm{O}_{4}$ catalyst}

Among various preparation methods for $\mathrm{CuFe}_{2} \mathrm{O}_{4}$ spinel, such as co-precipitation (CP), sol-gel combustion (SG), hydrothermal, microwave and solid-state reaction [41-44], the CP and SG methods are more attractive and advantageous due to the simpler operation, higher product purity and crystallinity. Compared to the CP method, the citrate-assisted SG method can save the tedious filtration and washing steps. Therefore, besides the $\mathrm{CuFe}_{2} \mathrm{O}_{4}-\mathrm{CP}$ sample, we also employed the SG method to prepare the $\mathrm{CuFe}_{2} \mathrm{O}_{4}$-SG sample, which showed even lower surface area $\left(3 \mathrm{~m}^{2} / \mathrm{g}\right)$ than the $\mathrm{CuFe}_{2} \mathrm{O}_{4}-\mathrm{CP}\left(5 \mathrm{~m}^{2} / \mathrm{g}\right)$. Furthermore, the $\mathrm{CuFe}_{2} \mathrm{O}_{4}-\mathrm{CP}$ and $\mathrm{CuFe}_{2} \mathrm{O}_{4}$-SG samples were pretreated in $\mathrm{H}_{2}$ at different temperatures to provide a series of reduced $\mathrm{CuFe}_{2} \mathrm{O}_{4}$ samples with different amount of surface copper species.

Fig. 1 shows the XRD patterns of various reduced $\mathrm{CuFe}_{2} \mathrm{O}_{4}$ samples. With the reduction temperature increasing from 150 to $300{ }^{\circ} \mathrm{C}$, the $\mathrm{CuFe}_{2} \mathrm{O}_{4}$-spinel phase (JCPDS 34-0425) gradually
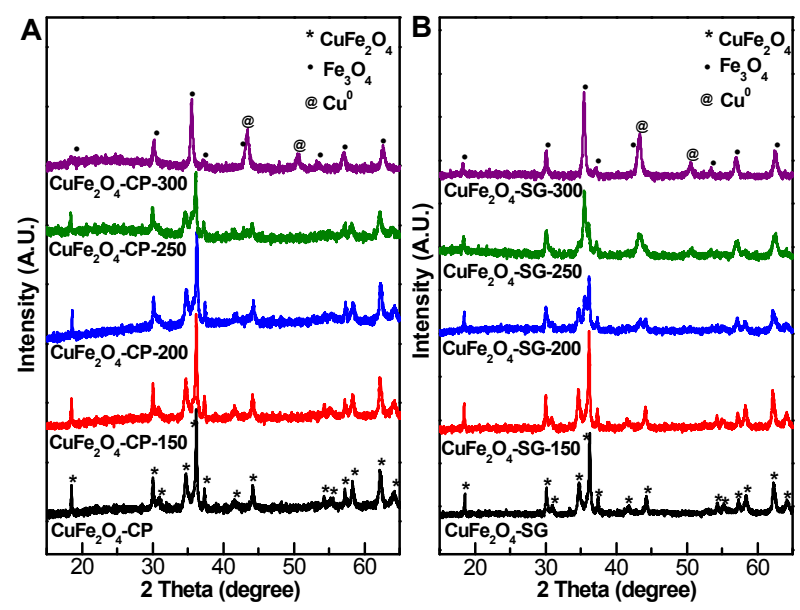

Fig. 1. XRD patterns of various reduced $\mathrm{CuFe}_{2} \mathrm{O}_{4}-\mathrm{CP}$ and $\mathrm{CuFe}_{2} \mathrm{O}_{4}-\mathrm{SG}$ samples.

changed to the mixture of $\mathrm{Fe}_{3} \mathrm{O}_{4}$ phase (JCPDS 19-0629) and metallic $\mathrm{Cu}^{0}$ phase (JCPDS 04-0836). Interestingly, the $\mathrm{CuFe}_{2} \mathrm{O}_{4}$-SG sample showed higher reducibility than the $\mathrm{CuFe}_{2} \mathrm{O}_{4}-\mathrm{CP}$, with $\mathrm{Fe}_{3} \mathrm{O}_{4}$ phase appearing at $200{ }^{\circ} \mathrm{C}$ in the former but at $250{ }^{\circ} \mathrm{C}$ in the latter. These XRD results are consistent with the $\mathrm{H}_{2}$-TPR results (Fig. 2), which confirm that the reduction of $\mathrm{CuFe}_{2} \mathrm{O}_{4}$-spinel to $\mathrm{Cu}^{0}$ and $\mathrm{Fe}_{3} \mathrm{O}_{4}$ starts below $200{ }^{\circ} \mathrm{C}$ for the $\mathrm{CuFe}_{2} \mathrm{O}_{4}-\mathrm{SG}$ and above $200{ }^{\circ} \mathrm{C}$ for the $\mathrm{CuFe}_{2} \mathrm{O}_{4}-\mathrm{CP}$. The AAS results evidently indicated that the acid-dissolvable copper species of the reduced $\mathrm{CuFe}_{2} \mathrm{O}_{4}-\mathrm{SG}$ (mainly $\mathrm{Cu}^{0}$ and its air-oxidized products such as $\mathrm{Cu}_{2} \mathrm{O}$ and $\mathrm{CuO}$ ) increased from 2.5 to $22.5 \mathrm{wt} \%$ with the reduction temperature increasing from 150 to $300{ }^{\circ} \mathrm{C}$. For the $\mathrm{CuFe}_{2} \mathrm{O}_{4}-\mathrm{SG}-200, \mathrm{CuFe}_{2} \mathrm{O}_{4}-\mathrm{SG}-250$, $\mathrm{CuFe}_{2} \mathrm{O}_{4}-\mathrm{CP}-250$ and $\mathrm{CuFe}_{2} \mathrm{O}_{4}-\mathrm{CP}-300$ samples, the fractions of the acid-dissolvable copper species were $7.7,16.8,4.3$ and 20.7 wt $\%$, respectively, which are lower than the theoretical value (26.6 wt\%) for the completely reduced $\mathrm{CuFe}_{2} \mathrm{O}_{4}$. It is notewor-

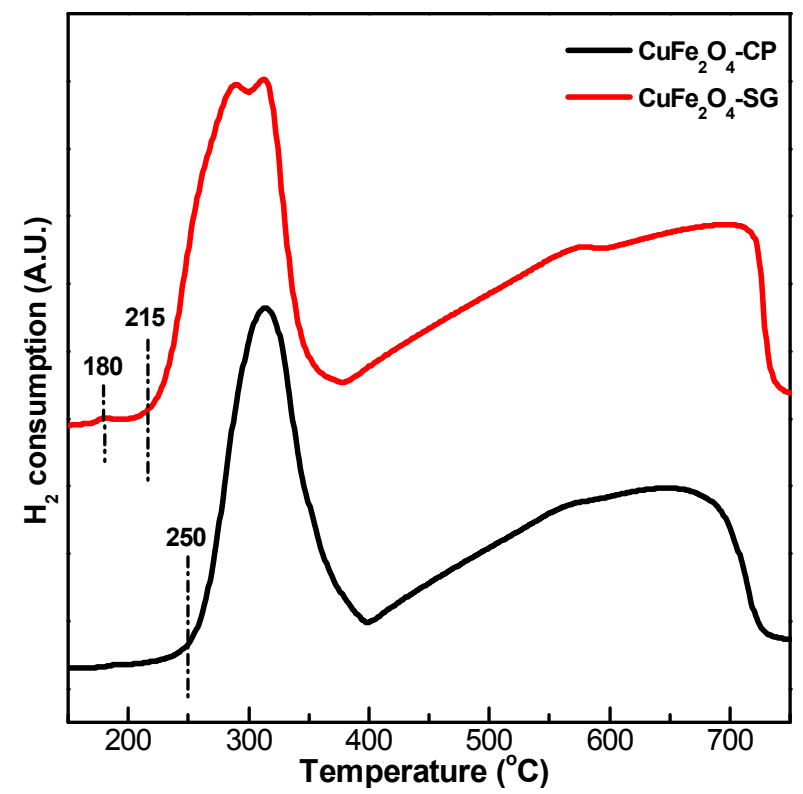

Fig. 2. TPR profiles showing $\mathrm{H}_{2}$ consumption for $\mathrm{CuFe}_{2} \mathrm{O}_{4}-\mathrm{CP}$ and $\mathrm{CuFe}_{2} \mathrm{O}_{4}$-SG samples. 
thy that no acid-dissolvable copper species was detected for the unreduced $\mathrm{CuFe}_{2} \mathrm{O}_{4}-\mathrm{CP}$ and $\mathrm{CuFe}_{2} \mathrm{O}_{4}$-SG samples. The HRTEM images of the reduced $\mathrm{CuFe}_{2} \mathrm{O}_{4}-\mathrm{CP}-300$ and $\mathrm{CuFe}_{2} \mathrm{O}_{4}-\mathrm{SG}-250$ (Fig. 3) also indicated the presence of metallic $\mathrm{Cu}^{0}$ and $\mathrm{Fe}_{3} \mathrm{O}_{4}$ phases. Lattice fringes of (111) planes for $\mathrm{Cu}^{0}$ and (311) planes for $\mathrm{Fe}_{3} \mathrm{O}_{4}$ were clearly observed, with the $d$ spacing distance around 0.21 and $0.25 \mathrm{~nm}$, respectively. These $d$ spacing data are in agreement with the XRD results.

The magnetic properties of the unreduced and reduced $\mathrm{CuFe}_{2} \mathrm{O}_{4}$ samples were examined by a vibrating sample magnetometer at room temperature (Fig. S1). The obtained magnetization hysteresis loops show a typical ferromagnetic behavior with a S-shape [43]. For the $\mathrm{CuFe}_{2} \mathrm{O}_{4}-\mathrm{SG}-250$ and $\mathrm{CuFe}_{2} \mathrm{O}_{4}-\mathrm{CP}-300$ samples, their magnetization hysteresis loops are similar to the previously reported $\mathrm{Fe}_{3} \mathrm{O}_{4}$ nanoparticles $[45,46]$, illustrating that these samples are superparamagnetic. Moreover, all the reduced $\mathrm{CuFe}_{2} \mathrm{O}_{4}$ samples can be facilely separated with a magnet, which is beneficial to catalyst recycling.

The light absorptions of the unreduced and reduced $\mathrm{CuFe}_{2} \mathrm{O}_{4}$ samples were examined by diffuse reflectance UV-vis spectra (Fig. 4). The unreduced $\mathrm{CuFe}_{2} \mathrm{O}_{4}-\mathrm{CP}$ and $\mathrm{CuFe}_{2} \mathrm{O}_{4}-\mathrm{SG}$ samples exhibit similar strong light absorption in the UV-vis region in the wavelength of $220-800 \mathrm{~nm}$, with the maximum absorption at $600 \mathrm{~nm}$. In contrast, there is an obvious improvement in light absorption for the reduced $\mathrm{CuFe}_{2} \mathrm{O}_{4}-\mathrm{CP}-300$ and $\mathrm{CuFe}_{2} \mathrm{O}_{4}$-SG-250, especially in the range of visible light. A distinguishable absorption peak at around $570 \mathrm{~nm}$ was observed for both reduced samples, which can be attributed to the LSPR absorption of CuNPs [33,34]. The enhanced visible light absorption of the reduced $\mathrm{CuFe}_{2} \mathrm{O}_{4}$ samples is consistent with the color change from brown to black after $\mathrm{H}_{2}$ reduction, and is conducive for the photocatalytic reaction irradiated by white LED.

We next studied the thermocatalytic and photocatalytic oxidative homocoupling of phenylacetylene over the various reduced $\mathrm{CuFe}_{2} \mathrm{O}_{4}-\mathrm{CP}$ and $\mathrm{CuFe}_{2} \mathrm{O}_{4}$-SG catalysts under the optimal reaction conditions as shown in Table 1 (Fig. 5). Interestingly, the reduced $\mathrm{CuFe}_{2} \mathrm{O}_{4}$-SG catalysts showed much higher activity than the corresponding $\mathrm{CuFe}_{2} \mathrm{O}_{4}-\mathrm{CP}$ catalysts in both thermocatalytic and photocatalytic OHA, primarily due to the more surface copper species in the former cases. Moreover, the catalytic activity increased with the reduction temperature in all cases. The $\mathrm{CuFe}_{2} \mathrm{O}_{4}-\mathrm{CP}-300$ showed a drastic increase in activity compared to the $\mathrm{CuFe}_{2} \mathrm{O}_{4}-\mathrm{CP}-250$, because the fraction of

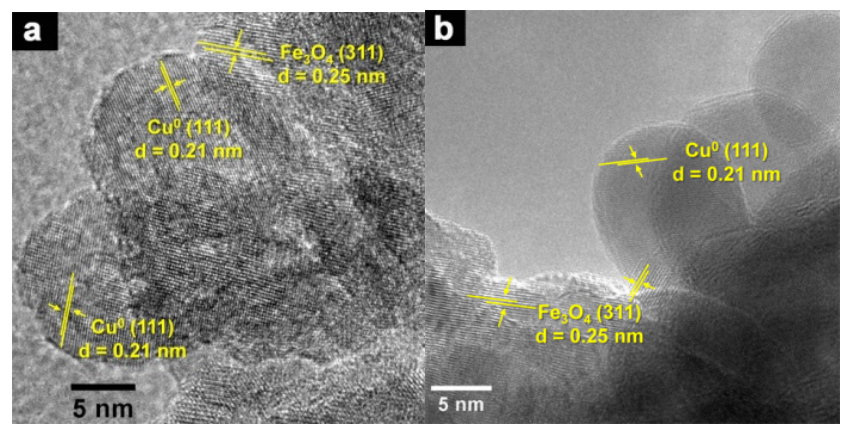

Fig. 3. HRTEM images for $\mathrm{CuFe}_{2} \mathrm{O}_{4}-\mathrm{CP}-300$ (a) and $\mathrm{CuFe}_{2} \mathrm{O}_{4}-\mathrm{SG}-250$ (b) samples.

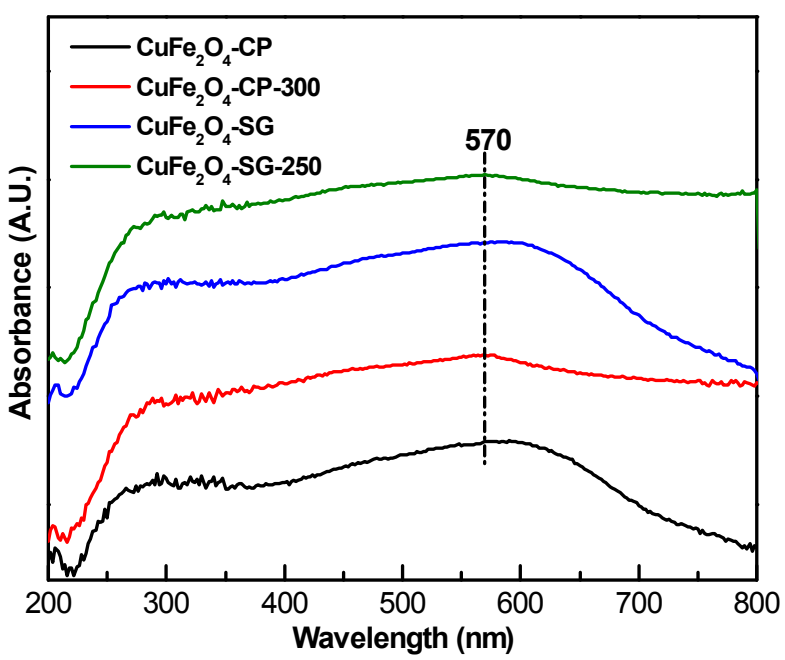

Fig. 4. UV-vis absorption spectra of typical unreduced and reduced $\mathrm{CuFe}_{2} \mathrm{O}_{4}$ samples.

acid-dissolvable copper species in the former (20.7 wt $\%$ ) is much higher than the latter (4.3 wt\%). In contrast, the $\mathrm{CuFe}_{2} \mathrm{O}_{4}$-SG-250 exhibited higher activity than the $\mathrm{CuFe}_{2} \mathrm{O}_{4}-\mathrm{CP}-300$, and the former catalyst achieved up to $90 \%$ and $95 \%$ yield of 1,3-diyne in the thermocatalytic and photocatalytic OHA, respectively. The similar catalytic activation in the thermocatalytic and photocatalytic reactions may be attributed to the similar amount of active copper species. It is evident that the activity of photocatalytic OHA at RT can be superior to that of thermocatalytic $\mathrm{OHA}$ at $120^{\circ} \mathrm{C}$. Compared to the $\mathrm{CuFe}_{2} \mathrm{O}_{4}$-SG-300, the $\mathrm{CuFe}_{2} \mathrm{O}_{4}$-SG-250 showed similar activity, suggesting that the moderate amount of surface copper species in the former is sufficient for the OHA reaction. Therefore, we selected the $\mathrm{CuFe}_{2} \mathrm{O}_{4}$-SG-250 as the optimal catalyst for further studies.

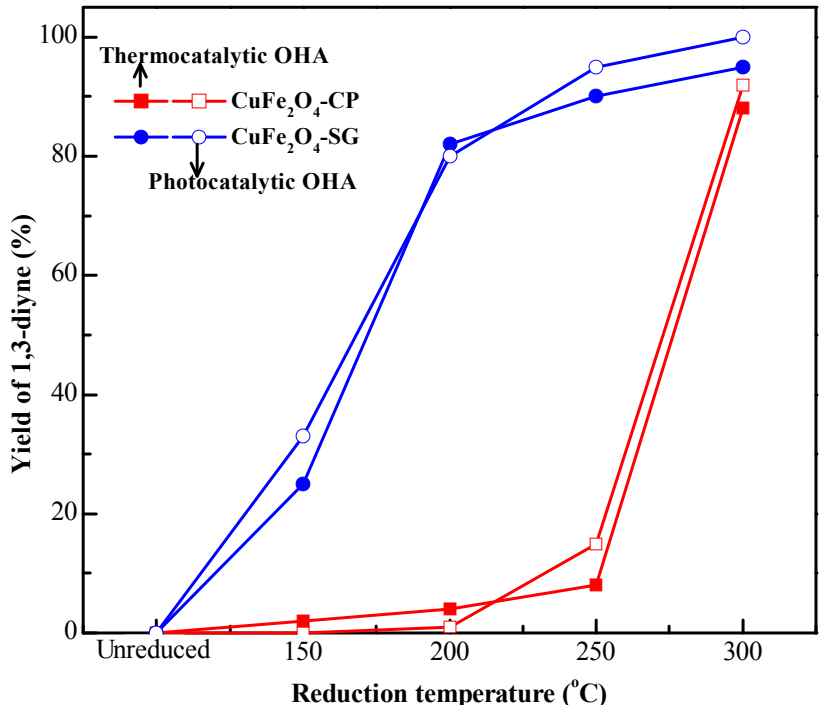

Fig. 5. Influence of preparation method and reduction temperature of $\mathrm{CuFe}_{2} \mathrm{O}_{4}$ on the catalytic activity in the thermocatalytic and photocatalytic oxidative homocoupling of phenylacetylene under the optimal reaction conditions listed in Table 1. 


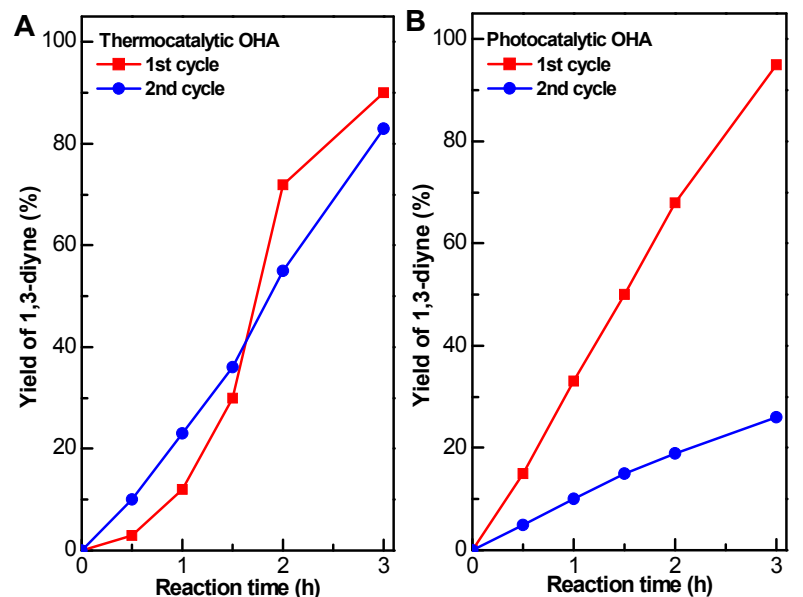

Fig. 6. Time course of 1,3-diyne yield in the thermocatalytic and photocatalytic oxidative homocoupling of phenylacetylene by using fresh and recycled $\mathrm{CuFe}_{2} \mathrm{O}_{4}$-SG-250 catalysts.

\subsection{Identification of active copper species in thermocatalytic and photocatalytic $\mathrm{OHA}$}

Since the unreduced $\mathrm{CuFe}_{2} \mathrm{O}_{4}$-spinel and bare $\mathrm{Fe}_{3} \mathrm{O}_{4}$ show no catalytic activity in both thermocatalytic and photocatalytic OHA, copper is thought to be the active site. Although metallic CuNPs enrich in the surface of the fresh $\mathrm{CuFe}_{2} \mathrm{O}_{4}-\mathrm{SG}-250$, they
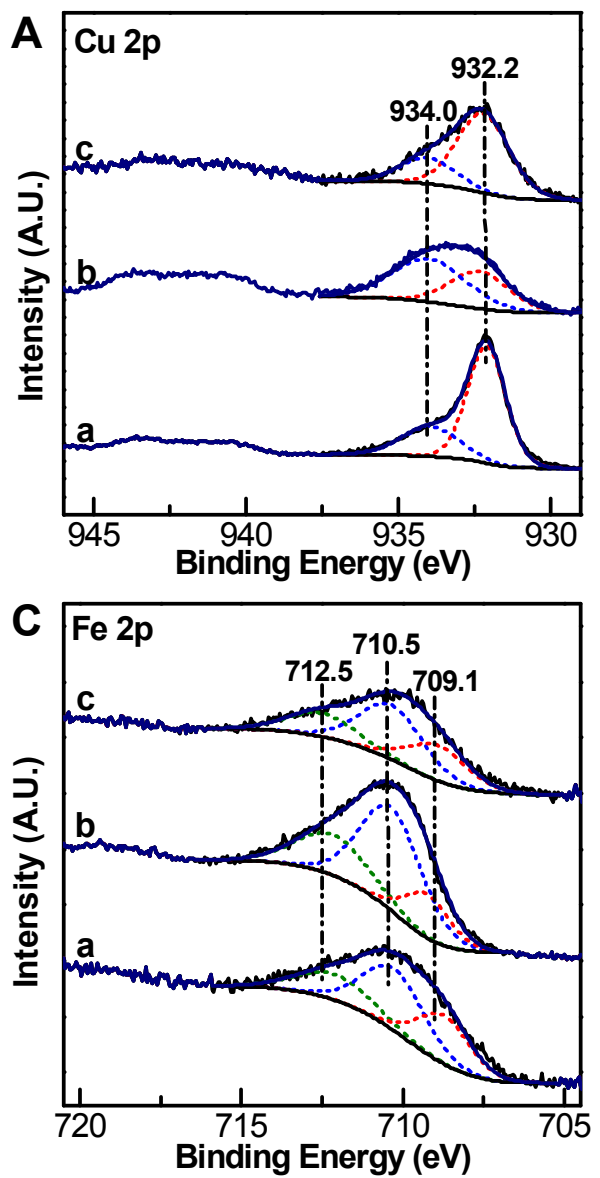

Fig. 7. XPS spectra of the fresh (a), thermocatalytically resued (b) and photocatalytically reused (c) $\mathrm{CuFe}_{2} \mathrm{O}_{4}-\mathrm{SG}-250$ catalysts. (A) Cu $2 p$; (B) Cu LMM; (C) Fe $2 p$; (D) $01 s$ are prone to oxidation to form $\mathrm{Cu}_{2} \mathrm{O}$ and $\mathrm{CuO}$ under the $\mathrm{O}_{2}$ atmosphere during the OHA reactions. Therefore, it is of importance to clarify the active copper species in the thermocatalytic and photocatalytic OHA. We firstly established the time course of yield of 1,3-diyne to evaluate the influence of the oxidation state change of copper on the catalytic activity (Fig. 6). Evidently, an induction period was observed for the thermocatalytic $\mathrm{OHA}$, indicating that the active copper species is not the metallic $\mathrm{Cu}^{0}$ but the oxidized $\mathrm{Cu}^{+}$or $\mathrm{Cu}^{2+}$. In line with this, the induction period was absent in the second reaction cycle, likely due to the presence of abundant surface $\mathrm{Cu}^{+}$or $\mathrm{Cu}^{2+}$ species in the recycled $\mathrm{CuFe}_{2} \mathrm{O}_{4}-\mathrm{SG}-250$ catalyst. For the photocatalytic OHA, in contrast, there was no induction period for the first reaction cycle, suggesting that metallic $\mathrm{Cu}^{0}$ is an active site. However, a significant decrease in activity was observed for the second cycle, primarily due to the facile oxidation of surface CuNPs by $\mathrm{O}_{2}$ during the reaction and the recycling. After the solid catalyst was removed at about $50 \%$ conversion of phenylacetylene, no further OHA was detected in the supernatant after $2 \mathrm{~h}$ under the same conditions. These results demonstrate that $\mathrm{CuFe}_{2} \mathrm{O}_{4}-\mathrm{SG}-250$ acts as a real heterogeneous catalyst in both thermocatalytic and photocatalytic OHA.

XPS was used to clarify the changes of surface copper, iron and oxygen species for the fresh $\mathrm{CuFe}_{2} \mathrm{O}_{4}-\mathrm{SG}-250$ catalyst and the one after reuse for the thermocatalytic and photocatalytic OHA reactions (Fig. 7). In the $\mathrm{Cu} 2 p_{3 / 2}$ XPS spectra, $\mathrm{Cu}^{2+}$ species
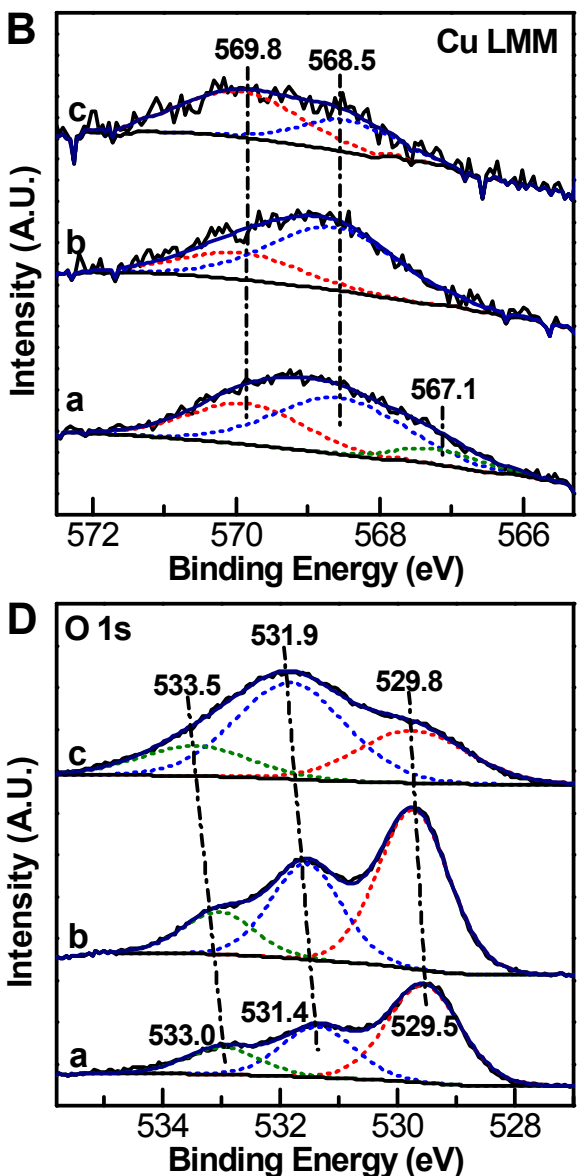
appear at $\sim 934 \mathrm{eV}[37,47]$, accompanied by the $\mathrm{Cu}^{2+}$ shakeup satellite peaks (938-945 eV). The lower binding energy (BE) peak at $\sim 932.2 \mathrm{eV}$ in the fresh and reused $\mathrm{CuFe}_{2} \mathrm{O}_{4}-\mathrm{SG}-250$ catalyst suggests the presence of $\mathrm{Cu}^{+}$or $\mathrm{Cu}^{0}$ species $[40,48]$. Because $\mathrm{Cu} 2 p_{3 / 2}$ XPS cannot differentiate between $\mathrm{Cu}^{+}$and $\mathrm{Cu}^{0}$, Auger $\mathrm{Cu}$ LMM spectra were used to confirm the presence of $\mathrm{Cu}^{0}, \mathrm{Cu}^{2+}$ and $\mathrm{Cu}^{+}$species in the fresh $\mathrm{CuFe}_{2} \mathrm{O}_{4}-\mathrm{SG}-250$ catalyst with the BE peak at 567.1, 568.5 and $569.8 \mathrm{eV}[42,49]$, respectively. The relatively low $\mathrm{Cu}^{0}$ fraction $(10 \%)$ and high $\mathrm{Cu}^{+} / \mathrm{Cu}^{2+}$ fraction in the fresh catalyst can be due to the facile oxidation of CuNPs in air [32]. It is worth noting that the surface $\mathrm{Cu}^{0} / \mathrm{Cu}^{+} / \mathrm{Cu}^{2+}$ fractions vary with the exposure time in air for the fresh catalyst, with longer exposure resulting in higher $\mathrm{Cu}^{+} / \mathrm{Cu}^{2+}$ fractions. The $\mathrm{Cu}$ LMM spectra in Fig. 7(B) suggested the absence of $\mathrm{Cu}^{0}$ species in the reused catalysts, with the surface $\mathrm{Cu}^{+}$fractions being $28 \%$ and $65 \%$ for the thermocatalytically and photocatalytically reused catalysts, respectively. These results indicate that the high reaction temperature in the thermocatalytic OHA facilitates the oxidation of surface $\mathrm{Cu}^{0}$ and $\mathrm{Cu}_{2} \mathrm{O}$ species to $\mathrm{CuO}$. In the $\mathrm{Fe} 2 p_{3 / 2}$ XPS spectra, three peaks at $\sim 709.1,710.5$ and $712.5 \mathrm{eV}$ can be deconvoluted, which can be assigned to $\mathrm{Fe}^{2+}$, octahedral $\mathrm{Fe}^{3+}$ and tetrahedral $\mathrm{Fe}^{3+}$ species $[50,51]$, respectively. Compared to the fresh $\mathrm{CuFe}_{2} \mathrm{O}_{4}-\mathrm{SG}-250$ catalyst, the surface $\mathrm{Fe}^{2+}$ fraction of the photocatalytically reused catalyst kept nearly unchanged $(\sim 30 \%)$, whereas that of the thermocatalytically reused catalyst decreased to $\sim 18 \%$, implying that partial $\mathrm{Fe}_{3} \mathrm{O}_{4}$ in the fresh catalyst could be oxidized to $\mathrm{Fe}_{2} \mathrm{O}_{3}$ during the thermocatalytic OHA. As shown in Fig. 7(D), three types of surface oxygen species can be identified from the $01 s$ XPS spectra. The peaks at low BEs (529.5-529.8 eV), medium BEs (531.4-531.9 eV), and high BEs (533.0-533.5 eV) are ascribed to the lattice oxygen ( $\left.\mathrm{O}^{2-}\right)$, oxygen vacancies or surface adsorbed oxygen $\left(\mathrm{O}_{2}^{-}, \mathrm{O}^{-}, \mathrm{OH}\right)$ groups, and adsorbed water, respectively [52]. It is evident that the surface oxygen species increased after the reuse, with the $\mathrm{O} /(\mathrm{Cu}+\mathrm{Fe})$ atomic ratio increasing from 1.5 to 3.0 for the thermocatalytically reused catalyst and to 5.0 for the photocatalytically reused catalyst. This is mainly due to the oxidation of $\mathrm{CuNPs}$ to $\mathrm{Cu}_{2} \mathrm{O}$ and $\mathrm{CuO}$ during the $\mathrm{OHA}$ reactions. The increase of oxygen vacancies in the reused catalysts presumably implies that the surface adsorbed oxygen species may involve in the thermocatalytic and photocatalytic OHA.

To clarify the role of $\mathrm{Cu}^{0} / \mathrm{Cu}^{+} / \mathrm{Cu}^{2+}$ species in $\mathrm{CuFe}_{2} \mathrm{O}_{4}$-SG-250 for the OHA reactions, the $\mathrm{Cu}^{0}$ powder, $\mathrm{Cu}_{2} \mathrm{O}$, $\mathrm{CuO}, \mathrm{Cu} / \mathrm{Fe}_{3} \mathrm{O}_{4}$ and $\mathrm{Cu} / \mathrm{TiO}_{2}$ were used as reference catalysts (Table 2). For the thermocatalytic OHA, CuO showed negligible activity, but $\mathrm{Cu}^{0}$ powder showed even higher activity than $\mathrm{Cu}_{2} \mathrm{O}$. Given the induction period, the higher activity of $\mathrm{Cu}^{0}$ powder can be due to the surface oxidized small-sized $\mathrm{Cu}_{2} \mathrm{O}$ particles. Thus surface $\mathrm{Cu}^{+}$should be the predominant active site in thermocatalytic OHA, which is consistent with the previously reported $\mathrm{CuO}_{x} / \mathrm{TiO}_{2}$ and $\mathrm{Cu}_{2} \mathrm{O}$ catalysts [24,53]. In contrast, $\mathrm{Cu}^{0}$ is confirmed to be the active species in photocatalytic OHA by the facts that (1) $\mathrm{Cu}_{2} \mathrm{O}$ and $\mathrm{CuO}$ are inactive, (2) freshly reduced $\mathrm{Cu} / \mathrm{Fe}_{3} \mathrm{O}_{4}, \mathrm{Cu} / \mathrm{TiO}_{2}$ and $\mathrm{CuFe}_{2} \mathrm{O}_{4}-\mathrm{SG}-250$ samples show significantly higher activity in photocatalysis than in thermocatalysis. The $\mathrm{CuFe}_{2} \mathrm{O}_{4}-\mathrm{SG}-250$ showed much higher turnover

\section{Table 2}

Thermocatalytic and photocatalytic OHA reactions over reference copper catalysts.

\begin{tabular}{|c|c|c|c|c|c|}
\hline \multirow{2}{*}{ Entry } & \multirow{2}{*}{ Catalyst } & \multicolumn{2}{|c|}{ Thermocatalytic $\mathrm{OHA}^{\mathrm{a}}$} & \multicolumn{2}{|c|}{ Photocatalytic OHA $^{\mathrm{b}}$} \\
\hline & & Yield c (\%) & TON $^{d}$ & Yield c (\%) & TON d \\
\hline 1 & $\mathrm{Cu}^{0}$ & 63 & 1.3 & 79 & 1.6 \\
\hline 2 & $\mathrm{Cu}_{2} \mathrm{O}$ & 25 & 0.5 & $<1$ & $\sim 0$ \\
\hline 3 & $\mathrm{CuO}$ & 2 & $<0.1$ & $<1$ & $\sim 0$ \\
\hline $4^{e}$ & $\mathrm{Cu} / \mathrm{Fe}_{3} \mathrm{O}_{4}$ & 61 & 6.1 & 75 & 7.5 \\
\hline $5^{e}$ & $\mathrm{Cu} / \mathrm{TiO}_{2}$ & 57 & 5.7 & 72 & 7.2 \\
\hline $6^{e}$ & $\mathrm{CuFe}_{2} \mathrm{O}_{4}-\mathrm{SG}-250$ & 65 & 6.5 & 83 & 8.3 \\
\hline
\end{tabular}

Reaction conditions: phenylacetylene $(0.2 \mathrm{mmol}), n$-dodecane $(0.1$ mmol) and catalyst with $50 \mathrm{~mol} \% \mathrm{Cu}$ in solvent $(2 \mathrm{~mL})$ with $\mathrm{O}_{2}$ balloon. a Thermocatalytic OHA was carried out in DMSO at $120{ }^{\circ} \mathrm{C}$ for $5 \mathrm{~h}$. b Photocatalytic OHA was performed in ethanol with white LED irradiation $\left(0.2 \mathrm{~W} / \mathrm{cm}^{2}\right)$ at ambient temperature $\left(30^{\circ} \mathrm{C}\right)$ for $5 \mathrm{~h} .{ }^{\mathrm{c}}$ Yields were determined by GC. ${ }^{d}$ Turnover number $(\mathrm{TON})=($ moles of converted phenylacetylene)/(moles of $\mathrm{Cu}$ ). ${ }^{\text {e }}$ Catalysts with $10 \mathrm{~mol} \% \mathrm{Cu}$ were used and reaction time was $5 \mathrm{~h}$.

number (TON 8.3) than $\mathrm{Cu}^{0}$ powder (TON 1.6), pointing to the beneficial effect of smaller CuNPs. Although bare $\mathrm{TiO}_{2}$ could not absorb visible light, $\mathrm{Cu} / \mathrm{TiO}_{2}$ showed similar photocatalytic activity as $\mathrm{Cu} / \mathrm{Fe}_{3} \mathrm{O}_{4}$ and $\mathrm{CuFe}_{2} \mathrm{O}_{4}$-SG-250, suggesting that metallic CuNPs may act as the main light absorber in this white LED-induced photocatalysis. The TON achieved by the photocatalytic OHA over $\mathrm{CuFe}_{2} \mathrm{O}_{4}$-SG-250 is comparable to the thermocatalytic OHA over various supported copper catalysts under ligand- and base-free conditions (Table S1). Interestingly, it is the first time to reveal that metallic $\mathrm{Cu}^{0}$ can serve as active species for the heterogeneous photocatalytic OHA, which is clearly different from the previous report on the $\mathrm{Cu}^{+}$-based homogeneous photocatalytic OHA [30].

\subsection{Influence of light source on heterogeneous photocatalytic $O H A$}

It is known that the conduction electrons of the coinage $(\mathrm{Cu}$, $\mathrm{Ag}$ and $\mathrm{Au}$ ) metal nanoparticles can gain visible light energy through the localized surface plasmon resonance effect, which occurs when the frequency of incident photons matches that of these oscillating conduction band electrons in metallic nanoparticles [54-56]. Since the LSPR absorption peak of CuNPs appears at around $570 \mathrm{~nm}[33,34]$, the photoexcited hot electron-driven OHA reaction would be influenced by the light intensity and wavelength. Therefore, the dependence of the photocatalytic activity over $\mathrm{CuFe}_{2} \mathrm{O}_{4}-\mathrm{SG}-250$ on the light intensity and wavelength was investigated.

As shown in Fig. 8(A), the 1,3-diyne yield had an almost linear growth with the increase in light intensity of the white LED. The increased catalytic activity is likely due to the more energetic electrons generated at higher irradiation intensity. This linear relationship suggests that the photocatalytic OHA is first order in the incident photon and is dominated by a single photon absorption event [55]. Under LED light with wavelengths of 580-680, 480-580, 400-500 and 400-780 nm, the 1,3-diyne yield was 2\%,53\%, 98\% and 95\% (Fig. 8(B)), respectively. Evidently, the red and green LED resulted in much lower pho- 

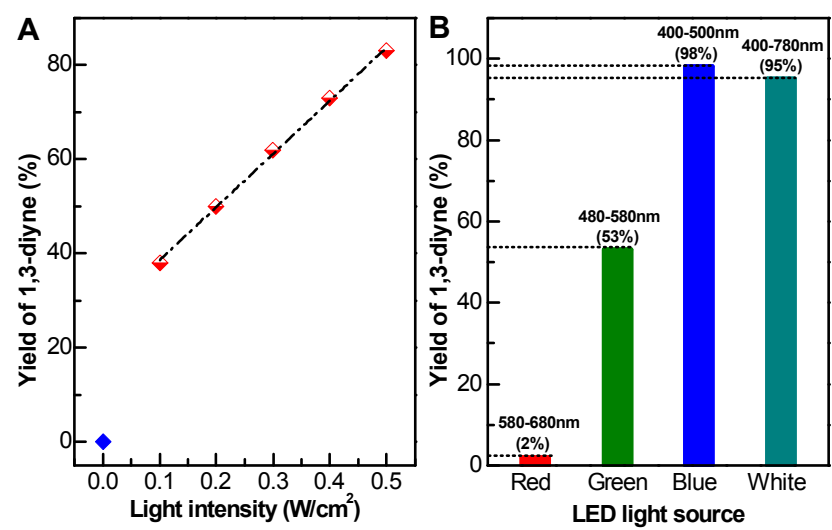

Fig. 8. Dependence of catalytic activity of $\mathrm{CuFe}_{2} \mathrm{O}_{4}$-SG-250 for the photocatalytic oxidative homocoupling of phenylacetylene on the intensity (A) and wavelength (B) of the LED irradiation.

tocatalytic activity than the blue and white LED. The fact that the light in the wavelength range of $400-500 \mathrm{~nm}$ contributes to the highest white LED-induced conversion is consistent with the spectral range of the white LED (Fig. S2), in which the blue region shows the highest intensity. It is noteworthy that, except for metallic CuNPs, the other components (such as $\mathrm{CuFe}_{2} \mathrm{O}_{4}$, $\mathrm{Fe}_{3} \mathrm{O}_{4}, \mathrm{Cu}_{2} \mathrm{O}$ and $\mathrm{CuO}$ ) of $\mathrm{CuFe}_{2} \mathrm{O}_{4}$-SG-250 may also absorb visible light and contribute to the photocatalysis. To exclude the visible light absorption by the support, the dependence of the photocatalytic activity over $\mathrm{Cu} / \mathrm{TiO}_{2}$ on the light wavelength was also investigated (Fig. S3). The green LED resulted in more comparable conversion (52\%) to the blue LED (65\%) and white LED (76\%), which underpins the primary contribution of the LSPR effect of CuNPs. When the heterogeneous photocatalytic OHA was conducted under natural sunlight (mean light intensity of $0.043 \mathrm{~W} / \mathrm{cm}^{2}$ ) instead of white LED at ambient temperature (about $30{ }^{\circ} \mathrm{C}$ ) for $8 \mathrm{~h}$, moderate yield $(63 \%)$ of 1,3-diyne was achieved. Although the detailed mechanism studies to clarify the nature of heterogeneous photocatalytic OHA are ongoing, the above findings reveal the possibility of using low-energy and -density light sources such as sunlight to drive the synthesis of 1,3-diynes on the CuNPs-based photocatalysts at ambient temperature under additive-free conditions.

\subsection{Applicability and reusability of $\mathrm{CuFe}_{2} \mathrm{O}_{4}-\mathrm{SG}-250$ catalyst}

A series of heterogeneous thermocatalytic and photocatalytic OHA using various terminal alkynes were conducted to investigate the general applicability of the $\mathrm{CuFe}_{2} \mathrm{O}_{4}$-SG-250 catalyst (Table 3). Aromatic alkynes with electron-donating or electron-withdrawing substituents achieved high yield (>90\%) towards the target 1,3-diyne products, with the photocatalytic efficiency comparable to the thermocatalysis. Neverthless, $\mathrm{CuFe}_{2} \mathrm{O}_{4}$-SG-250 showed much lower activity in the photocatalysis than in the thermocatalysis for aliphatic alkynes. This is probably due to the fact that the aliphatic alkynes lack the large conjugated $\pi$-bonds like the substituted phenylacetylenes, thus the interaction between the alkyne and CuNPs is weakened and the substrate activation is more difficult and needs higher en-

\section{Table 3}

Thermocatalytic and photocatalytic oxidative homocoupling of various terminal alkynes to 1,3-diynes over $\mathrm{CuFe}_{2} \mathrm{O}_{4}$-SG-250 catalyst.

\begin{tabular}{|c|c|c|c|c|c|}
\hline $\mathrm{R}=$ & $\equiv \overline{\mathrm{DMS}}$ & \multicolumn{2}{|c|}{ DMSO, $120^{\circ} \mathrm{C} / \mathrm{EtOH}, \mathrm{LED}, \mathrm{RT}$} & \multicolumn{2}{|c|}{$\mathrm{R}==\textrm{R}$} \\
\hline \multirow{2}{*}{ Entry } & \multirow{2}{*}{ Alkyne } & \multicolumn{2}{|c|}{ Thermocatalytic $\mathrm{OHA}^{\mathrm{a}}$} & \multicolumn{2}{|c|}{ Photocatalytic OHA } \\
\hline & & Time (h) & Yield c (\%) & Time (h) & Yield c (\%) \\
\hline 1 & & 3 & 90 & 3 & 95 \\
\hline 2 & & 6 & 98 & 6 & 98 \\
\hline 3 & & 6 & 98 & 8 & 98 \\
\hline 4 & & 8 & 93 & 8 & 96 \\
\hline 5 & & 9 & 97 & 10 & 98 \\
\hline 6 & & 3 & 77 & 10 & 83 \\
\hline 7 & & 3 & 81 & 10 & 40 \\
\hline
\end{tabular}

Reaction conditions: phenylacetylene $(0.2 \mathrm{mmol}), n$-dodecane $(0.1$ $\mathrm{mmol})$, catalyst $(20 \mathrm{mg})$, solvent $(2 \mathrm{~mL}), \mathrm{O}_{2}$ balloon. a Thermocatalytic OHA was carried out in DMSO at $120^{\circ} \mathrm{C}$. ${ }^{\mathrm{b}}$ Photocatalytic OHA was performed in ethanol with white LED irradiation $\left(0.2 \mathrm{~W} / \mathrm{cm}^{2}\right)$ at ambient temperature $\left(30^{\circ} \mathrm{C}\right) .{ }^{\mathrm{c}}$ Yields were determined by GC and GC-MS on the basis of the conversion of alkynes. Selectivity in all cases was $100 \%$ to diynes.

ergy or longer reaction time.

To evaluate the reusability of $\mathrm{CuFe}_{2} \mathrm{O}_{4}$-SG-250, it was easily separated by a magnet, thoroughly washed by ethyl acetate and ethanol, dried and reused directly in the OHA reactions (Fig. 9). The $\mathrm{CuFe}_{2} \mathrm{O}_{4}$-SG-250 could be recycled and reused at least five times in the thermocatalytic OHA without drastic loss of activity, and the yield of 1,3-diyne decreased gradually from $90 \%$ to
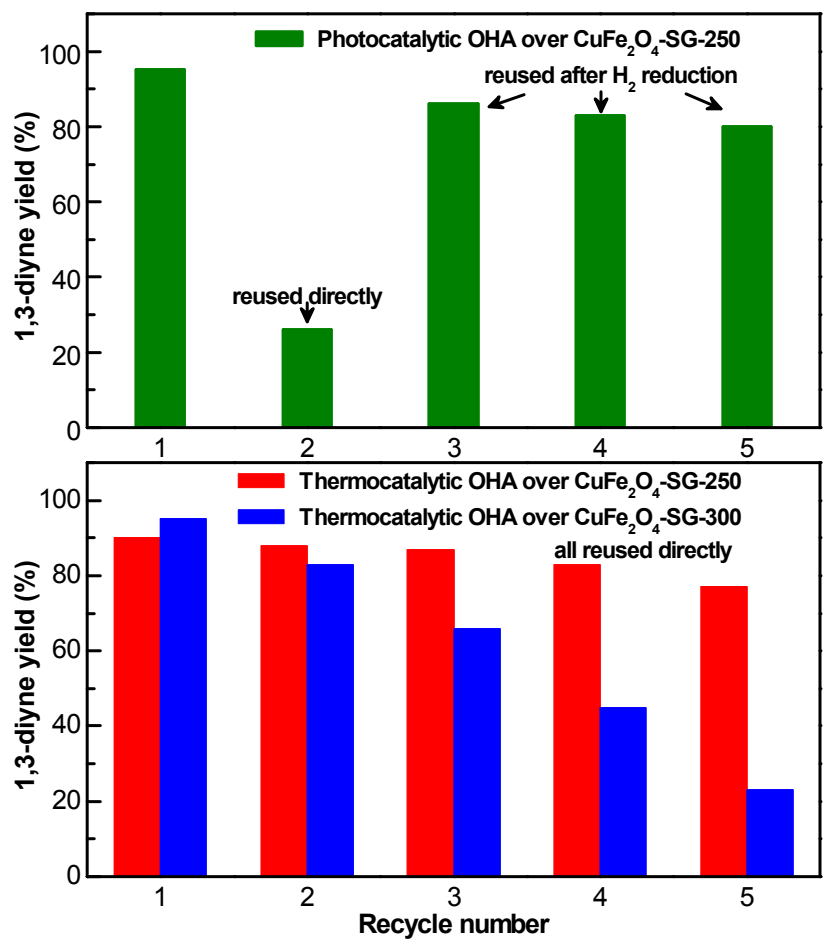

Fig. 9. Reusability of the $\mathrm{CuFe}_{2} \mathrm{O}_{4}-\mathrm{SG}-250$ and $\mathrm{CuFe}_{2} \mathrm{O}_{4}$-SG-300 catalysts in the thermocatalytic $\mathrm{OHA}$ and the $\mathrm{CuFe}_{2} \mathrm{O}_{4}-\mathrm{SG}-250$ catalyst in the photocatalytic OHA. 
$77 \%$ after the fifth cycle. The stability of $\mathrm{CuFe}_{2} \mathrm{O}_{4}-\mathrm{SG}-250$ is evidently better than the previously reported $\mathrm{CuO}_{x} / \mathrm{TiO}_{2}$ [24] and $\mathrm{CuO}_{x} / \mathrm{Fe}_{3} \mathrm{O}_{4}$ [26] catalysts, and is also better than $\mathrm{CuFe}_{2} \mathrm{O}_{4}$-SG-300, which deactivated significantly with the yield decreasing from $95 \%$ to $23 \%$ after the fifth cycle. To clarify the surface $\mathrm{Cu}^{+}$fraction changes of $\mathrm{CuFe}_{2} \mathrm{O}_{4}-\mathrm{SG}-250$ upon reuse, we performed further XPS analysis (Fig. S4). It is clear that the $\mathrm{Cu}^{+}$ fraction decreased from $37 \%$ to $33 \%$ after the $1^{\text {st }}$ cycle and to $28 \%$ after the $2^{\text {nd }}$ cycle for the thermocatalytic OHA. Although the surface $\mathrm{Cu}^{+}$fraction decreased to $16 \%$ after the $5^{\text {th }}$ cycle, the recycled catalyst was still efficient in the $6^{\text {th }}$ cycle $(\sim 72 \%$ yield). Therefore, the activity is not in direct proportion to the $\mathrm{Cu}^{+}$fraction, because not all $\mathrm{Cu}^{+}$species are available for the reaction. Despite of the gradual decrease in the $\mathrm{Cu}^{+}$fraction, the surface $\mathrm{Cu}^{+}$species are sufficient to achieve a high activity upon reuse. As indicated by the results of element analysis for the fifth recycled catalysts, the gradual deactivation in the thermocatalytic OHA can be mainly due to the copper leaching, with the acid-dissolvable copper species decreasing from 22.5 to 6.3 $w t \%$ for the $\mathrm{CuFe}_{2} \mathrm{O}_{4}-\mathrm{SG}-300$ and from 16.8 to $11.7 \mathrm{wt} \%$ for the $\mathrm{CuFe}_{2} \mathrm{O}_{4}-\mathrm{SG}-250$. It is clear that the partial reduction of $\mathrm{CuFe}_{2} \mathrm{O}_{4}$-SG spinel is more favorable than the complete reduction to enhance the stability of active copper species and retard the deactivation in the thermocatalytic OHA.

In contrast, the main reason for the deactivation in the photocatalytic $\mathrm{OHA}$ is not the copper leaching but the $\mathrm{Cu}^{0}$ oxidation. Although the fresh $\mathrm{CuFe}_{2} \mathrm{O}_{4}$-SG-250 catalyst suffers drastic deactivation in the second photocatalytic cycle due to the oxidation of CuNPs as indicated by the XPS results (Fig. 7), the photocatalytic activity can be largely recovered by reducing the recycled catalyst with $\mathrm{H}_{2}$ at $200{ }^{\circ} \mathrm{C}$. By this $\mathrm{H}_{2}$ pretreatment before the next cycle, $\mathrm{CuFe}_{2} \mathrm{O}_{4}$-SG-250 could be reused at least five times with the yield decreasing from $95 \%$ to $80 \%$ and the acid-dissolvable copper species decreasing from 16.8 to 13.8 wt $\%$ after the fifth cycle. Although it is more desirable to use a stable CuNPs catalyst in the photocatalytic $\mathrm{OHA}$ without the $\mathrm{H}_{2}$ pretreatment before reuse, the interesting structure-performance relationship of $\mathrm{CuFe}_{2} \mathrm{O}_{4}-\mathrm{SG}-250$ discussed above provide us a direction for future development of more efficient and stable CuNPs-based catalysts for the heterogeneous photocatalytic OHA.

\section{Conclusions}

We have shown that the prereduced copper-containing spinels can be used as effective heterogeneous catalysts for the thermocatalytic and photocatalytic oxidative homocoupling of terminal alkynes to conjugated 1,3-diynes. The magnetically separable $\mathrm{CuFe}_{2} \mathrm{O}_{4}$ shows the highest reducibility and has the most surface available copper species after $\mathrm{H}_{2}$ reduction to achieve the highest catalytic activity for the $\mathrm{OHA}$ reactions. The sol-gel combustion method and the partial reduction at $250{ }^{\circ} \mathrm{C}$ can result in the optimal $\mathrm{CuFe}_{2} \mathrm{O}_{4}$-SG-250 catalyst showing high activity and stability. It is found that surface $\mathrm{Cu}^{+}$species is the active site for the thermocatalytic OHA and metallic CuNPs are the active sites for the photocatalysis. The LSPR effect of CuNPs contributes to the visible light-induced conversion and enables photocatalytic OHA at ambient temperature, which is more convenient and energy-saving than the thermocatalytic OHA at $120{ }^{\circ} \mathrm{C}$. For the oxidative homocoupling of various aromatic alkynes, the photocatalytic efficiency is comparable to the thermocatalysis. The $\mathrm{CuFe}_{2} \mathrm{O}_{4}$-SG-250 catalyst can be magnetically separated and reused at least five times.

\section{Acknowledgments}

The authors thank the Analytical and Testing Center of Huazhong University of Science \& Technology, the Key Laboratory of Material Chemistry for Energy Conversion and Storage (Ministry of Education), and the Key Laboratory of Catalysis and Materials Science (State Ethnic Affairs Commission \& Ministry of Education of China) for use of the facilities.

\section{References}

[1] A. L. K. S. Shun, R. R. Tykwinski, Angew. Chem. Int. Ed., 2006, 45, 1034-1057.

[2] R. Gleiter, D. B. Werz, Chem. Rev., 2010, 110, 4447-4488.

[3] J. Liu, J. W. Y. Lam, B. Z. Tang, Chem. Rev., 2009, 109, 5799-5867.

[4] P. Siemsen, R. C. Livingston, F. Diederich, Angew. Chem. Int. Ed., 2000, 39, 2632-2657.

[5] W. Shi, A. Lei, Tetrahedron Lett., 2014, 55, 2763-2772.

[6] H. A. Stefani, A. S. Guarezemini, R. Cella, Tetrahedron, 2010, 66, 7871-7918.

\section{Graphical Abstract}

Chin. J. Catal., 2019, 40: 1505-1515 doi: S1872-2067(19)63418-2

\begin{abstract}
On the comparable activity in plasmonic photocatalytic and thermocatalytic oxidative homocoupling of alkynes over prereduced copper ferrite

Ying Zhu, Nan Deng, Meiqing Feng, Peng Liu* Huazhong University of Science and Technology

A green and efficient heterogeneous photocatalytic oxidative homocoupling of alkynes under visible-light irradiation was developed, which exhibits comparable activity to thermocatalysis.
\end{abstract}

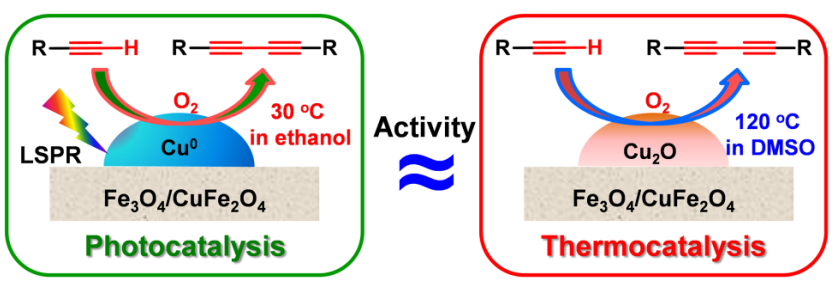


[7] F. Alonso, M. Yus, ACS Catal., 2012, 2, 1441-1451.

[8] J. Lei, L. Su, K. Zeng, T. Chen, R. Qiu, Y. Zhou, C.-T. Au, S.-F. Yin, Chem. Eng. Sci., 2017, 171, 404-425.

[9] S. M. Auer, R. Wandeler, U. Göbel, A. Baiker, J. Catal., 1997, 169, 1-12.

[10] B. C. Zhu, X. Z. Jiang, Appl. Organometal. Chem., 2007, 21, 345-349.

[11] Y. He, C. Cai, Catal. Sci. Technol., 2012, 2, 1126-1129.

[12] R. Xiao, R. Yao, M. Cai, Eur. J. Org. Chem., 2012, 4178-4184.

[13] F. Nador, M.A. Volpe, F. Alonso, A. Feldhoff, A. Kirschning, G. Radivoy, Appl. Catal. A, 2013, 455, 39-45.

[14] Q. Sun, Z. Lv, Y. Du, Q. Wu, L. Wang, L. Zhu, X. Meng, W. Chen, F.-S. Xiao, Chem. Asian J., 2013, 8, 2822-2827.

[15] H. Zhao, J. Xu, T. Wang, Appl. Catal. A, 2015, 502, 188-194.

[16] B. Lai, Z. Huang, Z. Jia, R. Bai, Y. Gu, Catal. Sci. Technol., 2016, 6, 1810-1820.

[17] X.-L. Shi, Q. Hu, F. Wang, W. Zhang, P. Duan, J. Catal., 2016, 337, 233-239.

[18] S. B. Ötvös, Á. Georgiádes, R. Mészáros, K. Kis, I. Pálinkó, F. Fülöp, J. Catal., 2017, 348, 90-99.

[19] H. Xu, K. Wu, J. Tian, L. Zhu, X. Yao, Green Chem., 2018, 20, 793-797.

[20] P. Kuhn, A. Alix, M. Kumarraja, B. Louis, P. Pale, J. Sommer, Eur. J. Org. Chem., 2009, 423-429.

[21] T. Oishi, T. Katayama, K. Yamaguchi, N. Mizuno, Chem. Eur. J., 2009, 15, 7539-7542.

[22] T. Oishi, K. Yamaguchi, N. Mizuno, ACS Catal., 2011, 1, 1351-1354.

[23] L. Liu, T. Matsushita, P. Concepción, A. Leyva-Pérez, A. Corma, ACS Catal., 2016, 6, 2211-2221.

[24] Z. Luo, S. A. Cetegen, R. Miao, T. Jiang, S.-Y. Chen, T. Jafari, Y. Zhang, S. L. Suib, J. Catal., 2016, 338, 94-103.

[25] S. Biswas, K. Mullick, S.-Y. Chen, D. A. Kriz, M. D. Shakil, C.-H. Kuo, A. M. Angeles-Boza, A. R. Rossi, S. L. Suib, ACS Catal., 2016, 6, 5069-5080.

[26] N. Sgrolli, N. Imlyhen, J. Volkman, A. M. Raspolli-Galletti, P. Serp, Mol. Catal., 2017, 438, 143-151.

[27] N. S. Lewis, Science, 2016, 351, aad1920.

[28] C. K. Prier, D. A. Rankic, D. W. C. MacMillan, Chem. Rev., 2013, 113, 5322-5363.

[29] M. Parasram, V. Gevorgyan, Chem. Soc. Rev., 2017, 46, 6227-6240.

[30] A. Sagadevan, V. P. Charpe, K. C. Hwang, Catal. Sci. Technol., 2016, 6, 7688-7692.

[31] M. B. Gawande, A. Goswami, F.-X. Felpin, T. Asefa, X. Huang, R.
Silva, X. Zou, R. Zboril, R. S. Varma, Chem. Rev., 2016, 116, 3722-3811.

[32] A. Marimuthu, J. Zhang, S. Linic, Science, 2013, 339, 1590-1593.

[33] X. Guo, C. Hao, G. Jin, H.-Y. Zhu, X.-Y. Guo, Angew. Chem. Int. Ed., 2014, 53, 1973-1977.

[34] Y. Huang, Z. Liu, G. Gao, G. Xiao, A. Du, S. Bottle, S. Sarina, H. Zhu, ACS Catal., 2017, 7, 4975-4985.

[35] Y.-L. Cui, X.-N. Guo, Y.-Y. Wang, X.-Y. Guo, Sci. Rep., 2015, 5, 12005.

[36] Z.-Y. Zhai, X.-N. Guo, G.-Q. Jin, X.-Y. Guo, Catal. Sci. Technol., 2015, 5, 4202-4207.

[37] P. Liu, E. J. M. Hensen, J. Am. Chem. Soc., 2013, 135, 14032-14035.

[38] W. Song, P. Liu, E. J. M. Hensen, Catal. Sci. Technol., 2014, 4, 2997-3003.

[39] P. Liu, X. Zhu, S. Yang, T. Li, E. J. M. Hensen, J. Catal., 2015, 331, 138-146.

[40] P. Liu, T. Li, H. Chen, E. J. M. Hensen, J. Catal., 2017, 347, 45-56.

[41] W. Hu, D. Li, Y. Yang, T. Li, H. Chen, P. Liu, J. Catal., 2018, 357, 108-117.

[42] K. Faungnawakij, N. Shimoda, T. Fukunaga, R. Kikuchi, K. Eguchi, Appl. Catal. A, 2008, 341, 139-145.

[43] Z. Xiao, S. Jin, X. Wang, W. Li, J. Wang, C. Liang, J. Mater. Chem., 2012, 22, 16598-16605.

[44] E. Casbeer, V. K. Sharma, X.-Z. Li, Sep. Purif. Technol., 2012, 87, $1-14$.

[45] J. Bao, W. Chen, T. Liu, Y. Zhu, P. Jin, L. Wang, J. Liu, Y. Wei, Y. Li, ACS Nano, 2007, 1, 293-298.

[46] S. Zhang, X. Zhao, H. Niu, Y. Shi, Y. Cai, G. Jiang, J. Harzard. Mater., 2009, 167, 560-566.

[47] X. Du, J. Huang, Y. Feng, Y. Ding, Chin. J. Catal., 2016, 37, 123-134.

[48] J. Huang, Y. Song, D. Ma, Y. Zheng, M. Chen, H. Wan, Chin. J. Catal., 2017, 38, 1229-1236.

[49] X. Dong, F. Li, N. Zhao, F. Xiao, J. Wang, Y. Tan, Appl. Catal. B, 2016, 191, 8-17.

[50] T. Kiyokawa, N. Ikenaga, Appl. Catal. A, 2017, 536, 97-103.

[51] M. Vijayaraj, C. S. Gopinath, J. Catal., 2006, 241, 83-95.

[52] P. Liu, J. Duan, Q. Ye, F. Mei, Z. Shu, H. Chen, J. Catal., 2018, 367, 115-125.

[53] N. Ma, X. Zeng, Chin. J. Org. Chem., 2018, 38, 1556-1561.

[54] S. Linic, P. Christopher, D. B. Ingram, Nat. Mater., 2011, 10, 911-921.

[55] M. J. Kale, T. Avanesian, P. Christopher, ACS Catal., 2014, 4, 116-128.

[56] X. Lang, X. Chen, J. Zhao, Chem. Soc. Rev., 2014, 43, 473-486.

\title{
预还原 $\mathrm{CuFe}_{2} \mathrm{O}_{4}$ 在等离子体光催化及热催化炔烃氧化自偶联反应中 具有可比活性的原因探究
}

\author{
朱 莹 ${ }^{\dagger}$, 邓 楠 ${ }^{\dagger}$, 封梅青, 刘 鹏 ${ }^{*}$ \\ 华中科技大学化学与化工学院, 湖北武汉 430074
}

摘要: 面对能源短缺、环境污染的两大世界难题, 人们将更多的目光投向了清洁、可持续的绿色能源一一太阳能. 绿色高 效的光催化转化被认为是替代传统热催化反应的最佳选择, 无其是可见光催化. 由Glaser首次提出的通过铜离子催化端基 炔氧化自偶联 $(\mathrm{OHA})$ 合成共轭1,3-二炔在天然产物、药物、光电子材料和聚合物合成中有着广泛的应用. 但是传统的热催 化OHA反应存在反应温度较高、需要添加含氮配体或碱性助剂、均相催化剂难以循环使用等问题. 因此发展反应条件温 和、无添加剂、可重复使用的多相光催化OHA反应体系势在必行.

鉴于 $\mathrm{Cu}^{+}$物种被认为是多相热催化和均相光催化 $\mathrm{OHA}$ 中的活性物种, 以及我们研究组前期发展了多种表面富含 $\mathrm{Cu}^{+}$物 种的尖晶石材料, 我们提出了将这些含铜尖晶石应用于多相光催化OHA反应. 研究发现, 只有预还原的含铜尖晶石才具有 
可见光催化活性, 其中预还原 $\mathrm{CuFe}_{2} \mathrm{O}_{4}$ 不仅在 $120{ }^{\circ} \mathrm{C}$ 热催化 $\mathrm{OHA}$ 中表现出最高的催化活性, 其在室温可见光催化 $\mathrm{OHA}$ 中 具有最高的催化活性, 这主要是由于 $\mathrm{CuFe}_{2} \mathrm{O}_{4}$ 具有较高的可还原性, 其在相同的还原温度 $300{ }^{\circ} \mathrm{C}$ 能获得最多的表面活性 $\mathrm{Cu}$ 物种. 因此, 我们进一步优化了 $\mathrm{CuFe}_{2} \mathrm{O}_{4}$ 的制备方法和还原温度, 发现采用溶胶-凝胶燃烧法 $(\mathrm{SG})$ 和 $250{ }^{\circ} \mathrm{C}$ 部分还原所制 备的 $\mathrm{CuFe}_{2} \mathrm{O}_{4}-\mathrm{SG}-250$ 催化剂具有更好的催化活性和稳定性,在多种末端炔烃的热催化和光催化OHA中均获得了高于 $90 \%$ 的1,3-二炔产率和能够与热催化相謧美的光催化活性.

由于未还原的 $\mathrm{CuFe}_{2} \mathrm{O}_{4}$ 样品及单独 $\mathrm{Fe}_{3} \mathrm{O}_{4}$ 在光催化和热催化OHA 中均没有活性, 因此表面铜是活性位点. 为了探究铜 物种的氧化态变化对催化活性的影响, 我们监测了1,3-二炔产率随反应时间的变化, 发现热催化有明显的诱导期而光催化 没有. 通过反应前后XPS价态分析, 并结合 $\mathrm{Cu}^{0} 、 \mathrm{Cu}_{2} \mathrm{O}$ 和 $\mathrm{CuO}$ 作为参照催化剂的反应结果, 我们发现表面氧化的 $\mathrm{Cu}_{2} \mathrm{O}$ 是热催 化OHA的活性物种, 而金属铜纳米颗粒(CuNPs)是光催化OHA的活性位点. 结合UV-Vis光谱结果及不同强度和波长可见 光对 $\mathrm{CuFe}_{2} \mathrm{O}_{4}-\mathrm{SG}-250$ 和 $\mathrm{Cu} / \mathrm{TiO}_{2}$ 光催化性能影响的探究, 我们认为 $\mathrm{CuNPs}$ 的局域表面等离子体共振(LSPR)效应有助于可见 光诱导的室温光催化OHA. 此外, 通过简单磁分离对 $\mathrm{CuFe}_{2} \mathrm{O}_{4}-\mathrm{SG}-250$ 的重复使用性进行了评估, 经过预还原处理该催化剂 至少可重复使用 5 次. 显然, 本文为开发基于CuNPs的高效、绿色的多相可见光催化工艺, 以取代能源和污染密集型的铜基 热催化反应提供了方向.

关键词: 炔烃; 氧化偶联; 铜铁尖晶石; 铜纳米颗粒; 表面等离子体共振

收稿日期: 2019-06-10. 接受日期: 2019-07-06. 出版日期: 2019-10-05.

*通讯联系人. 电话/传真: (027)87543632; 电子信箱: pengliu@hust.edu.cn

基金来源: 国家自然科学基金(21673088).

本文的电子版全文由Elsevier出版社在ScienceDirect上出版(http://www.sciencedirect.com/science/journal/18722067). 